\title{
Exploring Local Plant Resources for Anticancer Drugs with an Aim to Avoid or Minimize Cancer in Developing Countries: Egypt as an Example
}

\author{
Esmat A Hassan \\ Botany Department, Division of Agricultural and Biological Research, National Research Centre, Dokki, 12311, Cairo/Giza, Egypt
}

\begin{abstract}
The local resources herein meant plants and herbs naturally inhabit or successfully cultivated under normal Egyptian climate conditions during different seasons. Due to the increase in cancer cases observed among the Egyptian society and mainly in children, the objective is to improve growth and increasing quantitatively the active anti- carcinogenic constituents in certain plants. Experiments on Brassica and fennel plants were carried out. Anti-mutagenic effects of fennel seeds and its active substance anethole was however, tested. Thus we succeeded to use Brassica vegetables as amendments in processing a soft and dry bakery product. It is suggested; and after clinical studies; to be introduced as a dietary meal in the schools of the children as a try to avoid cancer in early stages of their growth. Herein, a glimpse on research activities relevant to the subject is briefed.
\end{abstract}

Key words: Anti-cancer, drugs, metabolites, plants, treatments.

\section{Introduction}

The naturally grown flora in Egypt is known to be originally distributed mainly in Sinai, St. Katherine Protectorate and the Northern Mediterranean cost belt [21]. Several plant species were collected by the native inhabitants of these areas for their domestic or for trade selling. Some of them may be useful as drug resources that can be applied in cancer therapy. In this respect, no enough records and scientific data is available on which further research activities can be proceed. During the last two decades, increasing number of in vitro and clinical studies suggested the potential role of certain plant metabolites in cancer care treatments. For example, the anti-cancer activity of black cumin (Nigella sativa) in the in vitro studies on mammals was reported in Jordan and in Saudi Arabia [3, 10] and of Ruta graviolens in Iran [24]. In Yemen the anticancer activities of selected medicinal plants were evaluated [22]. Whereas, in Marocco citral was found to inhibit cancer cell proliferation [8].

Corresponding author: Mrs. Esmat A Hassan, Ph.D., Prof., research fields: plant physiology/anatomy and histochemistry.
The present article is briefly pointing to results relevant to the subject. It introduce a practical step for cancer avoidance via connecting scientific research to the society. The collected results indicated that data regarding the potential benefits of exploring plants in cancer care research either as in vitro or in complementary clinical studies are certainly limited in Egypt. Thus, the author here in aimed to attract the attention to that, the geographic/climate of Egypt can be considered as a rich location to search and find unexplored local plant as sources to discover drugs to be used in cancer research and therapy. It is suggested that such an aim to be a multidisciplinary collaborative- dependent one between different researchers and expertise.

\section{Material and Methods}

In our research we establish methods to increase the metabolites from which active anti-cancer constituents originate in a cultivated plant to statistically significant levels [10, 12]. These metabolites were extracted and estimated using spectrophotometer, 
GLC and HPLC [5, 12]. On the other hand, antimutagenic tests of a certain seed plant and its extracted pure active substance on Swiss albino mice were performed [14]. Tissue culture technique was followed to produce and increase the yield of the target active compound of anti- carcinogenic effect in the drug part of a given plant [16]. Methods of processing soft bate and dry biscuits bakery products amended in broccoli $[1,15]$ and kohlrabi [13] were followed.

\section{Results and Discussion}

In ancient days, medication and its practice depended probably on repeated and experimented formulas/recipes originated from plant herbs directly on human/patient individuals. Advanced scientific methods and equipments are nowadays enabling the discovery of drugs from vegetables and fruits. In addition, the in vitro long term trials on mammals before trying to apply a given drug to be used in human medication became a must. A recent study on the traditional herbal knowledge in Middle East related to cancer care was performed [4, 11]. In Egypt, while the broccoli vegetable (Brassica oleraceae L.) is one of the highly consumed vegetable taken by the public in Egypt kohlrabi (Brassica caulorapa L.) is not yet known to them. Broccoli is known for its high content of the anti-oxidants`substance sulfuraphane, which was found to inhibit cancer cells [19]. The phenolic substances which are reported for their protective actions against cancer [5, 9] and heart diseases [7] were observed as a main constituent in Kohlrabi tissues [13]. On the other hand, Egyptians on all their income levels are greatly fond of fennel (Phoeniculum vulgare Mill.) seeds taste and flavor. Fennel seeds however, is usually added to the bakery products in the bakery houses. While the anti-mutagenic effects of fennel seeds and its pure active constituent anethole was observed [2, 20], to replace the seeds with anethole in such bakery products is in need to experimental clinical trials.
But, a cooperative research team had successfully reached to process a soft pate stuffed with fresh broccoli [15] and a dry biscuit product amended with kohlrabi flour [13]. The two products were accepted positively for their taste and flavor by registered tasters in the Department of Food Technology in the Institution. These results can be supported by the findings that considered constituents of the Brassica plants as cancer preventive substances [17, 23]. In our research we aimed to see for the possibility if our results can be clinically tested; at early stages of different cancer cases; by expertise in hospitals for children. Also if such a cheap baked product can be distributed in the schools to help in avoiding the exposure to cancer at early childhood ages .This could be more efficient in the low educated public locations and poor village inhabitants families.

\section{Conclusions}

From our results and literature, the author see the possibility of still virgin plants that can be subjected to multidisciplinary research activities for drug discovery, mainly to be used in cancer therapy. This will lead to increasing economic potential of such plants in cultivation, industry and marketing. Our preliminary results is needing clinical trials, a problem we faced and a step we failed to reach. This however, could encourage collaborative research teams from different regional countries to come together for such a human goal.

\section{References}

[1] Mahran, G. E. 1967. (Ph.D. London, Dr. Rer. Nat. Wurzburg). Medicinal Plants. Anglo-Egyptian Book Shop. 558.

[2] Abuharfeil, N. M., Maraqa, A. and Von, K. S. 2007. "Augmentation of Natural Killer Cell Activity in vitro Against Tumor Cells by Wild Plants from Jordan.” $J$. Ethnopharmacol 71 (1-2): 55-63.

[3] El-Awadi, M. E.; Esmat, A. H. 2010. "Physiological Responses of Fennel (Foeniculum Vulgare Mill) Plant to Some Growth Substances. The Effect of Certain Amino Acids and a Pyrimidine Derivative.” Journal of American Science. 6 (7) : 120-5. 
[4] Varamini, P., Sultani, M. and Ghaderi, A. 2009. “Cell Cycle Analyses and Cytotoxic Potential of Ruta Graveolens against Human Tumor Cell Lines.” Neoplasma. 56 (6): 490-3.

[5] Mothana, R. A., Gruenert, R., Bednarski, P. J. and Lindequist, U. 2009. "Evaluation of the in vitro Anticancer, Antimicrobial and Antioxidant Activities of Some Yemeni Plants Used in Folk Medicine.” Pharmzie. 64 (4): 260-8.

[6] Chaouki, W., Leger, D. Y., Liagre, B., Beneytout, J. L. and Hmamouchi, M. 2009. "Citral Inhibits Cell Proliferation and Induces Apoptosis and Cell Cycle Arrest in MCF-7 Cells” Fundam. clin. Pharmacology. 23 (5): 549-56.

[7] Esmat, A H. and Kamilia, A. A. 2010. "Studies on Plants with Special Reference to Their Potential Use in Cancer Care Research.” Improving Productivity and Accumulation of Principal Active Components in Fennel Plant. Egypt. J. of Appl. Sci. 25 (6A): 187-96.

[8] Cartea, M. E., Francisco, M., Soengas, P. and Velasco, P. 2010. "Phenolic Compounds in (Brassic) Vegetables." Molecules. 16 (1): 251-80.

[9] Esmat, A. H., Kamilia, A. A., Mohammad, E. E and Hanan, M. A. 2011b. "Anti-Mutagenic Effects of Fennel Plant (Foeniculum Vulgare Mill) Seeds and Pure Anethole : An in vitro Test on Mice. Nature and Science. 9 (12): 21-6.

[10] Eman, A. A. 2007. "Phytochemical and Biological Studies on Callus of Phgonia Arabica” M.Sc. Thesis. Faculty of Science, Zagazig University, Egypt.

[11] AACC. 1988. Approved methods of The American Assiation of Cereal Chemists. $8^{\text {th }}$ ed.INC. St., Paul, Minnesota. USA.

[12] Esmat, A. H., Ahmad, M. S. H. and Azza, A. A. H. 2013. "Chemical, Rheological and Sensory Evaluation of Pate Stuffed with Broccoli (Brassica oleraceae L.).” Polish J. Food \& Nutri. Scie. 63 (4): 245-52.

[13] Esmat, A. H., Ahmad, H. and Mohammad, E. E. 2011a. “Kohlrabi (Brassica caulorapa L.): A Potent Anticancer
Vegetable Processed in Backed Biscuits.” Nature and Science. 9 (8): 149-57.

[14] Ben-Arye, E., Schiff, E., Esmat, H., Mutafoglu, K., Lev-Ari, S. and Steiner, M. 2011. "Integrative Oncology in the Middle East: From Traditional Herbal Knowledge to Contemporary Cancer Care.” Annals of Oncology. 54.

[15] El-Obeid, A., Al-Harbi, S., Al-Jomah, N., Hassib, A. 2006. "Herbal Melanin Modulates Tumor Necrosis Factor Alpha (TNF-Alppha), Interleuin 6 (IL-6) and Vascular Endothelial Growth Factor (VEGF) Production.” Phytomedicine. 13 (5): 324-33.

[16] Li, Y., Zhang, T., Korkaya, H., Lui, S., Lee, H. F. and Newman, B. et al. 2010. "Sulfuraphane a Dietary Component of Broccoli/Broccoli Sprouts, Inhibit Breast Cancer Stem Cells.” Clin. Cancer Res. 16: 2580-90.

[17] Divisi, D., Tommaso, S. Di., Salvimini, S., Garramone, M. and Crisci, R. 2006. "Diet and Cancer." Acta Bio Med. 77: 118-22.

[18] Chen, L. and Zang, H. Y. 2007. “Cancer Preventive Mechanism of Green Tea Polyphenol(-)Epigallocatechine-3-Gallete.” Molecules. 12: 946-57.

[19] Al-Harbi M. M., Qurchi S., Ahmed, R. M.. Giangreco, A. A. and Shah, H. A. 1995. "Influence of Anethole Treatment on the Tumor Induced by Ehrlich Ascites Carcinoma Paw of Swiss Albino Mice.” Eur. J. Cancer Prev. 4: 307-18.

[20] Lubet, R. A., Steel, V. E., Eto, I., Juliana, M. M., Kellof, G. J., and Crubs, C. J. 1997. "Chemopreventive Efficacy of Anethole Trithione, N-Acetyle-Cysteine, Miconazole and Phenethylisothiocyanate in DMBA-induced Rat Mammary Cancer Model.” Int. J. Cancer. 72: 95-101.

[21] Herr, I. and Buchler, M. W. 2010. "Dietary Constituents and Other Cruciferous Vegetables: Implications for Prevention and Therapy of Cancer." Cancer Treat Rev. 36 (5): 377-83.

[22] Vainio, H. and Weiderpass, E. 2006. "Fruit and Vegetables in Cancer Prevention.” Nutr. Cancer. 54: 112-42. 